\title{
KKN-PPM: Pemberdayaan Masyarakat Pengelolaan Sanitasi Air Bersih pada Kawasan Perdesaan Prioritas Nasional di Desa Loeha Kecamatan Towuti
}

\author{
KKN-PPM: Empowerment of Clean Water Sanitation Management in the National Priority \\ Rural Area in Village Loeha, Towuti Sub-district
}

Andi Silfiana*
Sugiyanto
Chrecencya Nirmalarumsari
Department of Nursery, STIKES
Bhakti Pertiwi Luwu Raya,
Palopo, South Sulawesi,
Indonesia
*email:
sugiyantodarman@gmail.com
Kata Kunci
Desa Loeha
Desa Prioritas
Pemberdayaan Masyarakat
Sanitasi Air Bersih
Keywords:
Loeha Village
Priority Village
Community empowerment
Clean Water Sanitation
Published: December 2019

\begin{abstract}
Abstrak
Program Kuliah Kerja Nyata - Pembelajaran Pemberdayaan Masyarakat (KKNPPM) STIKES Bhakti Pertiwi Luwu Raya Palopo adalah salah satu kegiatan pengabdian kepada masyarakat yang rutin dilakukan oleh perguruan tinggi. Konsep KKN-PPM diarahkan agar dapat merubah konsep "working for the community" menjadi "working with community". Selain itu, untuk menjaga kontekstualisasinya, KKN-PPM dilakukan dengan mengubah paradigma pembangunan menjadi paradigma pemberdayaan. Kegiatan KKN-PPM ini bertujuan untuk memberdayakan dan membina masyarakat untuk hidup sehat sehingga derajat kesehatan masyarakat Desa Loeha dapat terwujud. Pelaksanaan program KKN-PPM ini dilakukan dengan menggunakan dua model yaitu: model eko-efesiensi, dan model Center for Environment and Society. Kegiatan KKN-PPM telah menghasilkan penyaringan air sederhana di setiap dusun di desa Loeha dengan berbasis bahan sederhana yang dapat diperoleh oleh warga di desa Loeha. Meningkatnya pengetahuan dan keterampilan masyarakat tentang tehnologi pengelolaan sanitasi air bersih. Memberikan manfaat pada derajat kesehatan masyarakat di desa Loeha dapat meningkat. Meningkatkan jiwa hidup bersih dan sehat, sehingga dapat memanfaatkan sumber air yang banyak sebagai sumber air yang bersih bagi kelangsungan hidup bermasyarakat. Masyarakat Desa Loeha sangat responsif dengan kegiatan ini, khususnya dalam pembuatan penyaringan air bersih sederhana, hal ini dibuktikan dengan cukup banyaknya masyarakat yang hadir.
\end{abstract}

\begin{abstract}
Real Work Lecture Program-Community Empowerment Learning (KKN-PPM) STIKES Bhakti Pertiwi Luwu Raya Palopo is one of the community service activities carried out routinely by universities. The KKN PPM concept is intended to change the concept of "working for the community" to "working with the community". In addition, to improve its contextualization, KKN-PPM is carried out by changing the development paradigm into an empowerment paradigm. The KKN-PPM activities are aimed at empowering and fostering the community to live healthy so that the health status of the village community can be fulfilled. The KKN-PPM implementation program is carried out using two models: the eco-development model, and the Center for Environment and Societal model. KKN-PPM activities have produced simple air filters in each hamlet in the village of Loeha with basic materials that can be obtained by residents in the village of Loeha. Increased knowledge and skills of the community about clean water sanitation management technology. It is expected that the level of public health in the village of Loeha can improve. Increase the soul of clean and healthy life, so that they can utilize a larger air source than a clean air source to save community life. The people of Loeha Village are very responsive to this activity, specifically, in making simple clean air filtration, this is evidenced by the considerable number of people present.
\end{abstract}




\section{PENDAHULUAN}

Penyakit diare merupakan salah satu penyakit yang sering menyebabkan kejadian luar biasa. Banyak faktor yang dapat mengakibatkan seseorang terkena penyakit diare, diantaranya adalah ketersediaan air bersih yang kurang (Nurfita, 2017). Air yang kurang bersih berkontribusi terhadap $88 \%$ kematian anak akibat diare di seluruh dunia (Ayuningrum \& Salamah, 2015). Anak - anak yang bertahan hidup seringnya menderita diare dan berkontribusi terhadap masalah gizi, sehingga menghalangi anak-anak untuk dapat mencapai potensi maksimal mereka. Kondisi ini selanjutnya menimbulkan implikasi serius terhadap kualitas sumber daya manusia dan kemampuan produktif suatu bangsa di masa yang akan datang (Napitupulu et al., 2017).

Salah satu potensi unggulan yang dapat dikembangkan melalui Kuliah Kerja Nyata - Pembelajaran Pemberdayaan Masyarakat (KKN-PPM) di Desa Loeha Kecamatan Towuti Kabupaten Luwu Timur Provinsi Sulawesi Selatan adalah melimpahnya sumber air, masyarakatnya memiliki sikap gotong royong yang sangat tinggi, memiliki rasa simpati dan empati terhadap sasama, serta Desa Loeha menjadi kawasan perdesaaan prioritas Nasional. Hal tersebut menjadi nilai yang penting dalam melakukan program pemberdayaan masyarakat pengelolaan sanitasi air bersih melalui pembuatan penyaringan air.

Pentingnya air bersih bagi kehidupan masyarakat di Desa Loeha dapat dilihat pada beberapa hal sebagai berikut, pertama, angka kejadian diare di Desa Loeha dapat berkurang. Penyakit diare masuk dalam daftar sepuluh penyakit terbanyak di wilayah kerja Puskesmas Bantilang dan Desa Loeha merupakan salah satu dari wilayah kerja puskesmas Bantilang. Kedua, status kesehatan masyarakat di Desa Loeha dapat meningkat dengan mengkomsumsi air bersih. Ketiga, masyarakat dapat mengetahui cara memperoleh air bersih. Keempat, masyarakat dapat mengerti dan memahami manfaat mengkomsumsi air bersih dalam kelangsungan hidup sehari - hari.

Hal ini juga sejalan dengan Instruksi Presiden Republik Indonesia Nomor 1 Tahun 2017 tentang Gerakan Masyarakat Hidup Sehat dengan Menetapkan kebijakan dan mengambil langkah-langkah sesuai tugas, fungsi, dan kewenangan masing-masing untuk mewujudkan Gerakan Masyarakat Hidup Sehat, melalui Peningkatan aktivitas fisik; Peningkatan perilaku hidup sehat; Penyediaan pangan sehat dan percepatan perbaikan gizi; Peningkatan pencegahan dan deteksi dini penyakit; Peningkatan kualitas lingkungan; dan Peningkatan edukasi hidup sehat.

Berdasarkan Focus Group Discussion (FGD) dengan masyarakat Desa Loeha, permasalahan yang muncul adalah minimnya pengetahuan masyarakat dalam melakukan penyaringan air. Padahal dengan mengetahui cara penyaringan air dan didukung oleh sumber air yang mudah diperoleh, potensi untuk memperoleh status kesehatan yang lebih tinggi lagi dapat diperoleh masyarakat di Desa Loeha. Melalui KKN-PPM, diharapkan dapat meningkatkan perilaku hidup sehat dan peningkatan kualitas lingkungan terutama mengenai kebersihan air.

Berdasarkan identifikasi dari permasalahan yang dihadapi masyarakat di Desa Loeha kecamatan Towuti Kabupaten Luwu Timur, dan FGD antara Tim Pengusul KKN-PPM dengan perwakilan masyarakat di Desa Loeha, solusi yang disepakati dan yang akan dilakukan melalui KKN-PPM sebagai berikut:

1. Melakukan penyuluhan tentang pentingnya air bersih bagi kelangsungan hidup masyarakat dan penyuluhan tentang cara membuar penyaringan air bersih

2. Melakukan pengelolaan sanitasi air bersih seperti membuat percontohan penyaringan air bersih 
3. Melakukan pendampingan kepada masyarakat yang melakukan pengelolaan sanitasi air bersih seperti pembuatan penyaringan air bersih

4. Memberikan motivasi untuk membangun rasa kebersihan dalam diri masyarakat melalui program pemberdayaan masyarakat dalam malakukan sanitasi air bersih dengan menggunakan alat percontohan.

\section{METODOLOGI}

Alat dan bahan yang digunakan dalam kegiatan Pengabdian ini diantaranya adalah drum, pipa PVC dengan diameter $3 / 4$ inci, kran air, pasir, kerikil, potongan batu, ijuk, arang tempurung, gergaji, parang, besi, bor, kuas, ember, dan cangkul. Jenis sumber air baku yang digunakan adalah air sumur atau air tanah, dengan target pengguna adalah rumah tangga dan komunal/Kelompok.

Gusdi et al. (2017) mengemukakan bahwa metode pembuatan penyaringan air sederhana meliputi:

1. Membuat pipa penyaringan

Langkah awal dalam membuat penyaringan air, terlebih dahulu dilakukan pembuatan pipa penyaringan air. Dimana diperlukan 2 pipa PVC dengan diameter 0,75 inci dengan panjang $35 \mathrm{~cm}$. Pipa PVC tersebut dilubangi secara teratur sepanjang $20 \mathrm{~cm}$ lalu bagian pipa yang dilubangi dibalut dengan ijuk kemudian ijuk diikat dengan tali plasitik. Kemudian salah satu ujung pipa dibuat ulir. Setelah itu pipa penyaringan dipasang pada drum pengendapan dan penyaringan dengan jarak $10 \mathrm{~cm}$ dari dasar drum.

2. Membuat drum pengendapan

Langkah selanjutnya adalah dengan membuat drum pengendapan. Terlebih dahulu membuat lubang dengan bor besi $10 \mathrm{~cm}$ dari dasar drum pada dinding drum untuk pipa penyaringan. Setelah itu memasang pipa penyaringan yang sudah dibalut pada soket yang sudah tersediah, lalu memasang kran air pada ujung pipa, kemudian buat lubang pada dasar drum dengan tutup.

3. Membuat drum penyaringan

Langkah yang terakhir adalah dengan membuat drum penyaringan dengan cara membuat lubang untuk pemasangan pipa penyaring dengan jarak 10 cm dari dasar drum, kemudian isi drum berturut turut dengan krikil setebal $20 \mathrm{~cm}$, ijuk $5 \mathrm{~cm}$, pasir 20 $\mathrm{cm}$, arang tempurung $10 \mathrm{~cm}$, ijuk $10 \mathrm{~cm}$, dan potongan bata $10 \mathrm{~cm}$. Setelah drum sudah diisi oleh bahan - bahan penyaringan, selanjutnya tempatkan drum pengendapan dan penyaringan pada posisi bertingkat, lalu kran - kran ditutup dan air diisikan ke dalam drum pengendapan. Setelah 30 menit air dari drum pengendapan dialirkan ke dalam drum penyaringan. Aliran air yang keluar dari drum penyaringan disesuaikan dengan masukan dari drum pengendapan.

4. Penatalaksanaan

Pengelolaan air bersih ini dilakukan dengan mendatangkan para masyarakat Desa Loeha. Selain itu, untuk memfasilitasi masyarakat terhadap akses pembuatan penyaringan air bersih, maka tim pengusul akan berkoordinasi dengan pemerintah setempat.

Kegiatan Program KKN-PPM dilaksanakan oleh Tim Pengusul, dengan memadukan beberapa model pola pemberdayaan masyarakat yang telah populer sebagai berikut:

1. Model eko-efesiensi (eco-development). Konsep ekoefesiensi yang oleh Soemarwoto (2001) diartikan sebagai perpaduan sinergis antara komponen ekologi dan ekonomi. Ekoefesiensi bertujuan memperoleh efesiensi dari aspek ekonomi maupun 
ekologi yang menyangkut keberlanjutan lingkungan hidup sebagai penopang kehidupan manusia. Program Kemitraan Masyarakat ini didesain untuk meningkatkan proses kemandirian dan pemberdayaan sasaran namun tidak meninggalkan hubungan yang simbiosis dengan lingkungan hidup serta jaminan keberlanjutan pada masa mendatang.

2. Model Center for Environment and Society. Model Center for Environment and Society, didefinisikan sebagai suatu usaha berkelanjutan yang merupakan suatu cara memanfaatkan barang alamiah dan jasa yang tidak merusak lingkungan dan memanfaatkan pengetahuan serta keterampilan mitra yang dipilih. Unsur social capital yang dapat dijadikan faktor pendukung pelaksanaan program kegiatan ini salah diantaranya adalah konsep Tudang Sipulung (duduk bersama menyelesaikan masalah), yang berujung pada meningkatnya sikap gotong royong.

\section{HASIL DAN PEMBAHASAN}

\section{Koordinasi Aparat Pemerintahan dan Pihak Puskesmas}

Salah satu tahapan penting dalam pelaksanaan program kerja KKN-PPM adalah melakukan koordinasi dengan aparat pemerintahan dan pihak puskesmas untuk mengatasi permasalahan sanitasi air bersih diwilayah Desa Loeha yaitu kondisi air yang keruh terutama pada musim hujan. Selain membentuk koordinator di setiap dusun, dilakukan juga observasi secara langsung oleh Kepala Desa Loeha, Kepala dusun, Pihak Puskesmas Bantilang, Dosen pendamping dan koordinator mahasiswa untuk melakukan pengecekan ulang kondisi pipa saluran air yang menyalurkan air ke rumah warga dari sumber mata air. Hal ini diperlukan untuk memastikan bahwa kondisi air yang keruh memang berasal dari sumbernya bukan karena masalah pada pipa saluran airnya. Dan hasil yang didapatkan, terdapat \pm 200 meter pipa saluran air yang perlu diganti karena mengalami kerusakan yang cukup parah.

Dengan adanya koordinasi ini diharapkan mahasiswa KKN-PPM mampu merencanakan segala program kerja berdasarkan masalah yang telah ditemukan dan juga mampu meningkatkan kinerja pelaksanaan program tersebut. Darmanto (2018) mengatakan dalam penelitiannya bahwa budaya kerja, disiplin kerja dan koordinasi secara simultan (bersama-sama) berpengaruh positif dan signifikan terhadap kinerja karyawan PT Kereta Api Indonesia (Persero) Daop 1 Jakarta. Dengan adanya peningkatan budaya kerja, disiplin kerja dan koordinasi maka kinerja karyawan juga akan mengalami peningkatan.

Selain perencanaan masalah pengelolaan sanitasi air bersih, dilakukan juga koordinasi dengan pihak Puskesmas Bantilang terkait rencana pelaksanaan promosi kesehatan terkait air bersih, perilaku hidup bersih dan sehat dan juga penyakit yang berkaitan dengan kondisi air yang kurang bersih, guna meningkatkan pengetahuan masyarakat. Planning of action yang telah disusun oleh mahasiswa disosialisasikan kepada pihak Puskesmas untuk mendapatkan kesesuaian dengan program Puskesmas. Koordinasi sangat penting dilakukan untuk keberhasilan suatu program. Menurut penelitian Nazarudin (2016) menyatakan bahwa secara simultan vareabel koordinasi dan pengawasan berpengaruh signifikan terhadap efektivitas keberhasilan suatu organisasi. Sementaran menurut penelitian yang dilakukan oleh Raflis (2015) komunikasi dalam tim kerja memberikan pengaruh positif terhadap keberhasilan suatu kegiatan. Oleh karena itu untuk komunikasi dan koordinasi penting dilakukan oleh mahasiswa dengan pihak terkait demi keberhasilan program KKN-PPM. Kegiatan koordinasi dengan aparat desa dan pengecekan kondisi pipa air disajikan pada Gambar 1. 


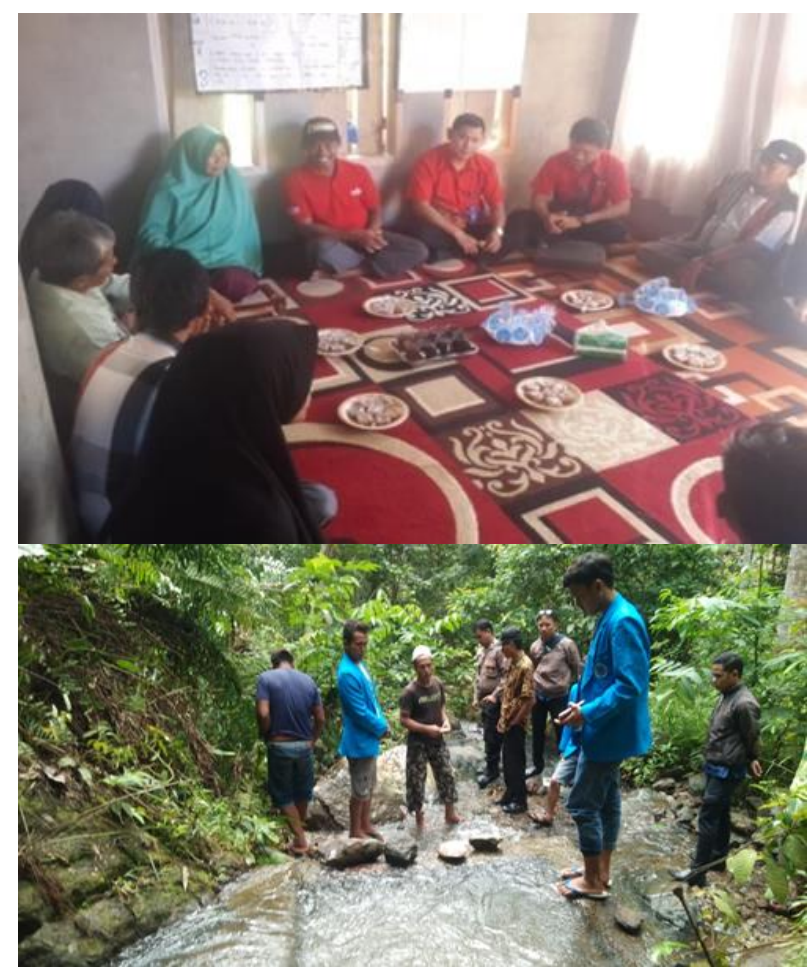

Gambar 1. Koordinasi dengan aparat desa (atas) dan pengecekan kondisi pipa air (bawah)

Bimbingan Teknik Pemilihan Bahan Pembuatan Penyaringan Air Bersih

Setelah koordinasi dilakukan oleh masing-masing penanggung jawab dusun bersama dengan Kepala dusun untuk menentukan waktu dan tempat pelaksanaan pelatihan pembuatan penyaringan air bersih, selanjutnya disiapkan segala alat dan bahan yang diperlukan untuk pembuatan penyaringan tersebut. Alat dan bahan yang diperlukan dalam pembuatan penyaringan air sederhana diantaranya adalah drum/ember besar, pipa, kran air, ijuk, arang, pasir, kerikil, spons (Gusdi et al., 2017). Masing-masing koordinator dusun dan tim menyiapkan setiap alat dan bahan yang dibutuhkan. Selain itu warga juga diberikan bimbingan mengenai bagaimana cara menyiapkan bahan yang diperlukan untuk membuat penyaringan air sederhana. Setiap bahan yang disiapkan yaitu kerikil, ijuk, arang, pasir dan spons, semuanya harus dicuci dahulu sampai benar-benar bersih.
Bimbingan ini bertujuan untuk meningkatkan pengetahuan dan kemampuan warga dalam memilih bahan-bahan yang digunakan untuk membuat penyaringan air. Dalam hal ini warga dibimbing dan diberikan informasi mengenai cara memilih bahan yang baik. Kegiatan proses pemilihan dan pencucian bahan disajikan pada Gambar 2.

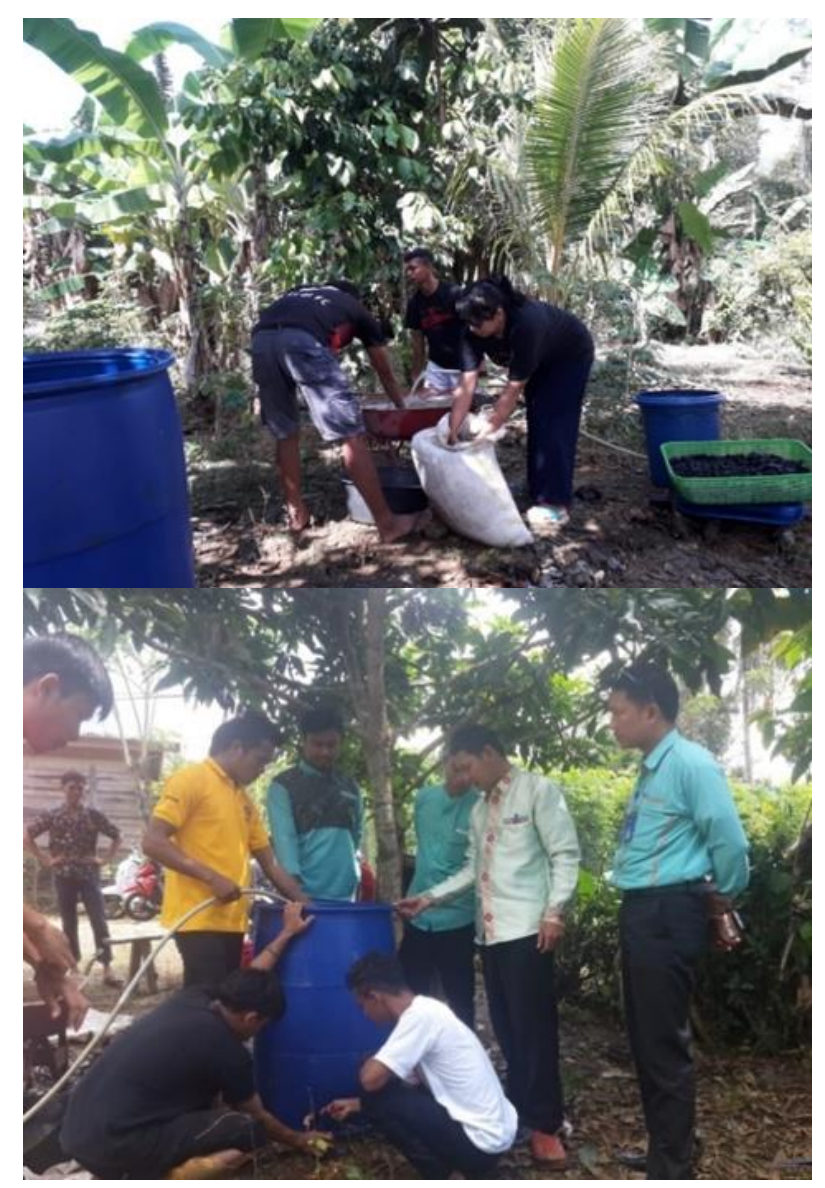

Gambar 2. Proses pemilihan bahan (atas) dan pencucian bahan (bawah)

Bimbingan sendiri memiliki defenisi sebagai suatu proses pemberian bantuan yang terusmenerus dan sistematis dari pembimbing kepada yang dibimbing agar tercapai kemandirian dalam pemahaman diri dan perwujudan diri dalam mencapai tingkat perkembangan yang optimal dan menyesuaikan diri dengan lingkungannya (Sukardi, 2000).

Dengan adanya bimbingan ini warga di harapkan mampu untuk menyelesaikan masalah dan mampu menciptakan suatu produk (penyaringan air) yang 
memiliki kualitas yang baik dan tahan lama. Bimbingan sangat berpengaruh terhadap pruduk yang di hasilkan oleh masyarakat dalam hal ini penyaringan air. Erica (2015) dalam penelitiannya mengatakan bahwa terdapat pengaruh antara variabel bimbingan belajar dengan variabel prestasi belajar dan produk yang dihasilkan.

\section{Pelatihan Pembuatan Penyaringan Air Bersih}

Selanjutnya secara bergantian sesuai dengan jadwal yang telah disepakati bersama, koordinator dusun dari mahasiswa yang didampingi oleh dosen pendamping memberikan pelatihan teknis cara pembuatan penyaringan air bersih secara sederhana kepada masyarakat di dusun masing-masing. Bahan yang telah disiapkan disusun kedalam drum/ember besar sesuai urutannya, yaitu kerikil, ijuk, arang, ijuk, pasir, kerikil, spons. Semua bahan disusun berdasarkan perbandingan jumlah yang telah ditentukan. Setelah penyaringan air sederhana tersusun, selanjutnya air dialirkan kedalam drum/ember. Beberapa saat kemudian kran air dibuka untuk mengalirkan air yang sudah disaring. Hal ini dilakukan beberapa kali sampai air yang keluar menjadi jernih. Setelah air yang keluar jernih, maka penyaringan air bisa digunakan untuk kebutuhan sehari-hari (Gusdi et al., 2017).

Pelatihan dan bimbingan teknik pembuatan Penyaringan Air Bersih sangat penting dilakukan kepada warga Desa Loeha supaya warga mengatahui secara detail dan benar cara pembuatan penyaringan air bersih, sehingga natinya warga masyarakat dapat mengimplementasikannya di rumah mereka sendiri. Dokumentasi kegiatan bimtek sendiri disajikan pada

\section{Gambar 3 .}

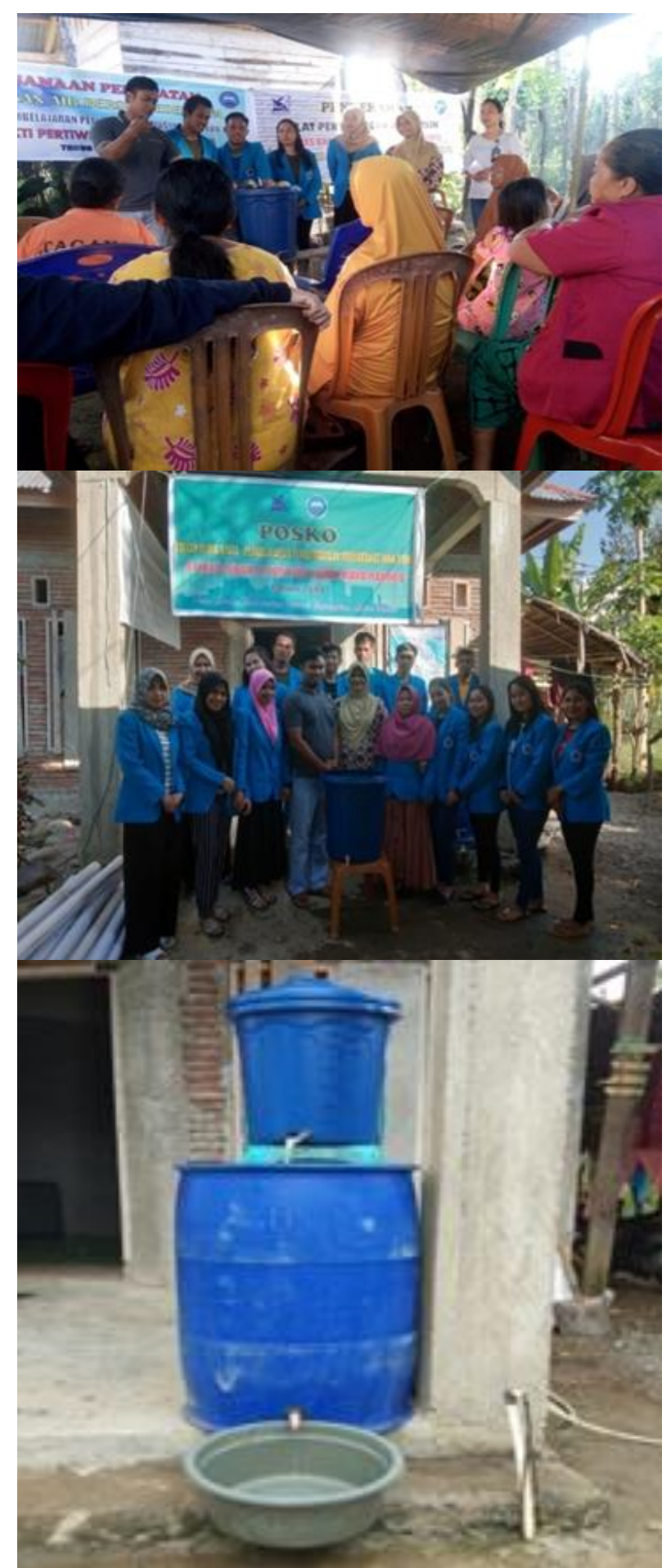

Gambar 3. Bimbingan Teknik Pembuatan Penyaringan Air Bersih (atas), foto bersama warga peserta Bimtek (tengah), dan alat penyaring yang telah dibuat (bawah)

Bimbingan teknik adalah suatu kegiatan dimana para peserta diberi pelatihan-pelatihan yang bermanfaat dalam meningkatkan kompetensi peserta/warga. Dengan adanya bimbingan teknik dan pendampingan 
ini diharapkan nantinya warga Desa Loeha dapat menghasilkan produk yang berkualitas dalam hal ini penyaringan air bersih, Pemberian bimbingan teknik dan pendampingan yang maksimal secara tidak langsung akan menghasilkan produk yang maksimal pula. Awaluddin (2009) dalam penelitiannya mengemukakan bahwa program pelaksanaan Bimtek membantu auditor menjalankan proses teknis dalam melakukan audit sesuai dengan program kerja yang dilakukan dua kali dalam setahun dan pelaksanaan Bimtek meningkatkan kompetensi dan mengembangkan profesi sebagai auditor.

Pelaksanaan Bimtek dan pemdampingan ini juga bertujuan agar peserta/warga dalam membuat penyaringan air bersih sesuai dengan prosedur yang telah ditetapkan. Warga yang mengikuti pelatihan teknis pembuatan penyaringan air bersih sangat antusias mengikuti kegiatan yang berlangsung. Hal ini terlihat dari banyaknya warga di masing-masing dusun yang datang dalam kegiatan bimtek sesuai jadwal yang telah dibuat. Warga juga terlihat banyak yang mengajukan pertanyaan terkait dengan pembuatan penyaringan air tersebut. Selain itu warga bisa menyaksikan secara langsung bahwa air yang pada awalnya keruh menjadi jernih setelah melalui beberapa kali proses penyaringan. Dan juga alat dan bahan yang digunakan cukup mudah didapatkan. Sehingga membuat warga memiliki motivasi yang tinggi untuk membuat penyaringan air bersih dirumahnya.

\section{Pemasangan Pipa Air Bersih dari Sumber Air Kerumah Warga}

Air adalah suatu senyawa kimia berbentuk cairan yang tidak berwarna, tidak berbau dan tak ada rasanya. Air merupakan kebutuhan dan bagian yang tidak bisa dipisahkan dari kehudupan manusia. Asupan air yang tidak sehat akan menimbulkan masalah bagi kehidupan manusia (Budi Imam S et al, 2011). Sebagai zat yang dibutuhkan tubuh, air memiliki fungsi penting dalam tubuh manusia yaitu; 1) sebagai pembentuk sel dan cairan tubuh, 2) sebagai pengatur suhu, 3) sebagai pelarut, 4) sebagai pelumas dan bantalan, 5) sebagai media transportasi, 6) sebagai media eliminasi toksin dan produk sisa metabolism (Food and Nutrition Research Institute, 2002). Dokumentasi kegiatan pemasangan disajikan pada Gambar 4.

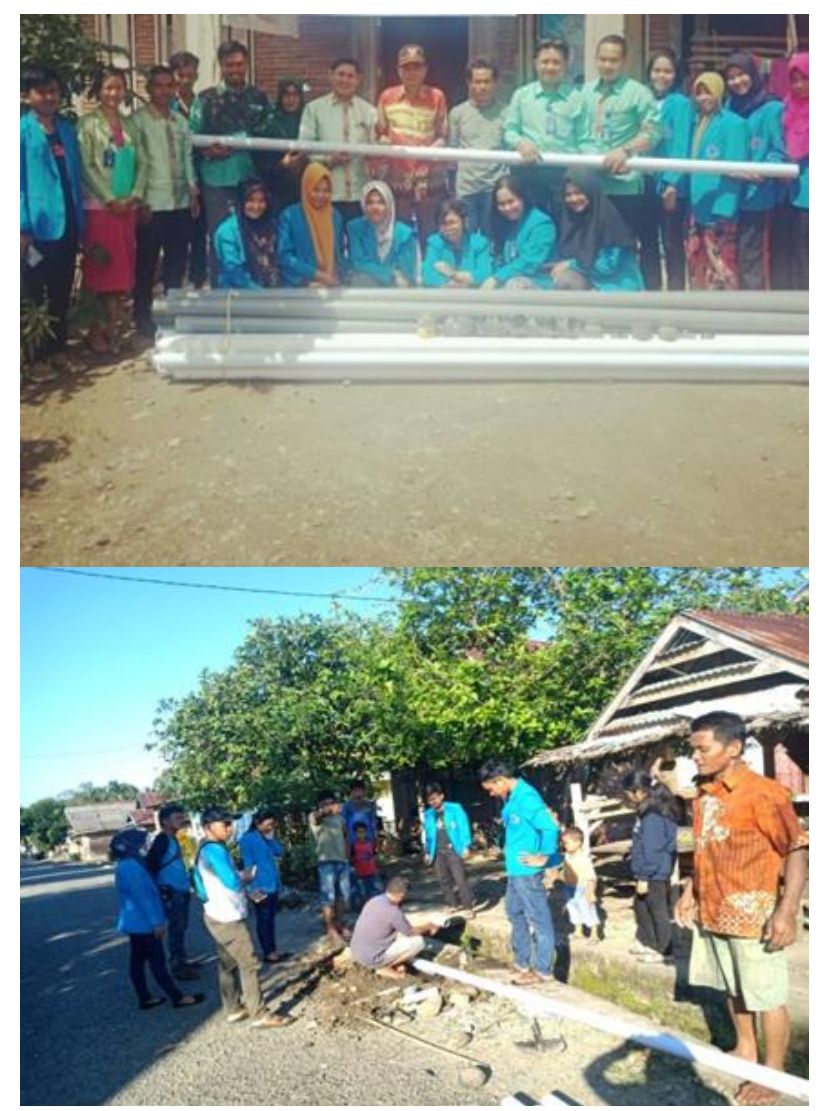

Gambar 4. Pipa yang akan digunakan (atas) dan Pemasangan Pipa Air Bersih (bawah)

Pengembangan kualitas dan kuantitas air bersih merupakan salah satu pengembangan infrastruktur lingkungan yang perlu mendapat perhatian dari semua pihak, mulai dari pusat sampai ke daerah-daerah. Ketersediaan air, terutama air bersih, menjadi salah satu penentu kualitas hidup suatu masyarakat.

Air bersih adalah air yang digunakan untuk keperluan sehari-hari yang kualitasnya memenuhi syarat kesehatan dan dapat diminum apabila telah dimasak (Utami \& Handayani, 2017). Banyak faktor yang mempengaruhi ketersediaan air bersih. Salah satunya 
adalah kondisi sumber air. Ketika air dari sumber mata air tidak terlalu keruh, namun jika kondisi pipa saluran air bocor atau tidak layak lagi maka akan mengganggu distribusi air bersih yang disalurkan kerumah warga. Hal inilah yang dialami oleh mayarakat di Desa Loeha.

Oleh karena itu untuk mengatasi masalah ketersediaan air bersih maka mahasiswa KKN-PPM bergotongroyong dengan warga memperbaiki dan memasang kembali pipa saluran air yang berada di sekitar wilayah Desa Loeha sesuai dengan hasil observasi yang pernah dilakukan sebelumnya. Kegiatan ini juga melibatkan aparat pemerintahan Desa Loeha, kepala dusun, dan pihak Puskesmas Bantilang. Warga sangat antusias terlibat dalam kegiatan ini, karena dengan adanya pipa yang baru diharapkan akan membuat air yang sampai kerumah warga menjadi lebih jernih. Dan hasil yang didapatkan, terdapat \pm 200 meter pipa saluran air yang perlu diganti karena mengalami kerusakan yang cukup parah. Kegiatan perbaikan pipa ini mendapat sambutan hangat dari warga, karena selama ini akibat kerusakan pada pipa saluran air masyarakat mengalami kesulitan mendapatkan air. Kegiatan ini melibatkan seluruh warga yang berada di Desa Loeha mulai dari aparat desa, warga masyarakat dan didampingi oleh mahasiswa KKN-PPM.

Penyuluhan Kesehatan Tentang Pentingnya Air Bersih dan Penyakit Diare

Selain melakukan bimbingan teknis pembuatan penyaringan air bersih, dilakukan juga penyuluhan kesehatan tentang pentingnya air bersih bagi kesehatan manusia. Hal ini dilakukan sesuai dengan hasil FGD dan juga hasil pengkajian yang telah dilakukan oleh mahasiswa bahwa tingkat pengetahuan masyarakat Desa Loeha mengenai pentingnya air bersih masih kurang. Warga masyarakat beranggapan bahwa selama ini sudah terbiasa menggunakan air yang tidak jernih, terutama pada musim hujan ketika kondisi air menjadi semakin keruh maka warga hanya mengendapkan air tersebut selama beberapa waktu sebelum menggunakan untuk kebutuhan sehari-hari, termasuk untuk kebutuhan memasak dan air minum. Anggapan tersebut muncul akibat dari kurangnya pengetahuan masyarakat terhadap konsisi sanitasi air bersih. Maka penyuluhan kesehatan tentang sanitasi air bersih sangat penting dilakukan untuk meningkatkan pengetahuan dan pemahaman masyarakat dalam memngkonsumsi air bersih. Penyuluhan kesehatan ini diharapkan dapat merupah prilaku masyarakat kearah yang lebih baik, yaitu prilaku hidup bersih dan sehat (PHBS). Raharjo et al. (2016) dalam penelitiannya mengatakan bahwa ada pengaruh yang signifikan dari penyuluhan kesehatan terhadap prilaku PHBS masyarakat $(0,00<0,05)$.

Selain penyuluhan pentingnya air bersih juga dilakuan penyuluhan tentang penyakit diare yang berkaitan dengan bahaya kurangnya penggunaan air bersih. Moll et al. (2007) menjelaskan bahwa perbaikan konstruksi, perbaikan sanitasi serta akses air minum yang memenuhi syarat berdampak dalam penurunan prevalensi kejadian diare. Robertson et al. (2007) menjelaskan lebih jauh bahwa, konstruksi sumber air bersih yang baik akan melindungi kontaminasi air dengan menghambat suplai makanan bagi bakteri sehingga bakteri tidak berkembang. Dengan demikian konstruksi air yang baik akan berpengaruh terhadap keberadaan bakteri yang dapat menyebabkan diare. Bakteri yang sering berkembang pada sanitasi air yang tercemar adalah bakteri Escherichia coli. Menurut penelitian Musawir et al. (2014) mengemukakan bahwa ada hubungan E. coli $(\mathrm{p}=0,000)$ dengan kejadian diare pada balita. Sumber air yang telah tercemar E. Coli memiliki peluang yang cukup besar untuk menyebabkan penyakit diare pada manusia terutama pada balita. 
Penyuluhan dilakukan oleh mahasiswa dan didampingi oleh dosen pendamping, selain dengan cara mengundang warga masyarakat untuk datang di posko, juga dilakukan di masjid ketika selesai dilaksanakan kegiatan sholat jumat dan juga dilakukan ketika ada kegiatan posyandu. Warga tampak antusias dalam mengikuti penyuluhan khususnya mengenai bahaya kurangnya penggunaan air bersih. Dokumentasi kegiatan penyuluhan disajikan pada Gambar 5 .

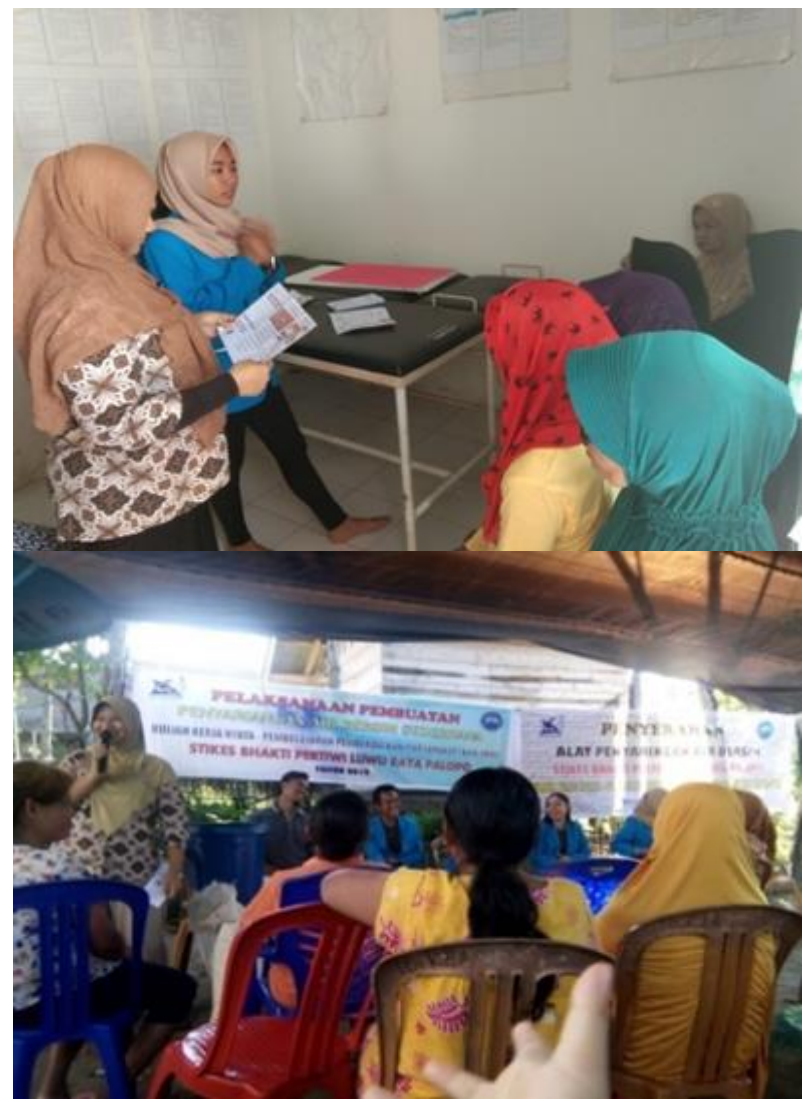

Gambar 5. Persiapan penyuluhan (atas) dan Penyuluhan Kesehatan Tentang Air Bersih dan Penyakit Diare (bawah)

Secara geografis desa Loeha merupakan desa yang berada pada pesisir danau dan perbukitan, dimana sumber air berasal dari air sumur dan mata air (sungai). Dari hasil pengamatan kondisi air di desa Loeha tidak layah konsumsi, karena kondisinya berwarna (keruh), berbau dan berasa. Hal ini sangat tidak diajurkan untuk dikonsumsi secara langsung karena akan menimbulkan berbagai penyakit, salah satunya adalah diare.
Penggunaan sumber air sebagai air minum tanpa tindakan pengolahan atau treatment merupakan faktor yang sangat mempengaruhi terjadinya kejadian diare. Kebiasaan di masyarakat sampai saat ini masih ada yang menkonsumsi air minum tanpa dimasak sampai mendidih. Berdasarkan hasil penelitian Sutomo (1987) disimpulkan bahwa ada hubungan antara sumber air minum yang dikonsumsi di rumah-rumah pada daerah pedesaan dan responden yang menggunakan air bersih memiliki kecenderungan lebih kecil menderita penyakit diare. Sebaliknya responden yang tidak menggunakan air bersih memiliki kecenderungan menderita penyakit diare.

\section{KESIMPULAN}

Berdasarkan hasil kegiatan tersebut maka dapat disimpulkan bahwa terjadi peningkatan pengetahuan dan keterampilan masyarakat tentang teknologi pengelolaan sanitasi air bersih, dan juga telah dihasilkannya penyaringan air bersih sederhana di setiap dusun di Desa Loeha dengan berbasis bahan sederhana yang dapat diperoleh oleh warga di Desa Loeha. Penyaringan air yang sudah ada diharapkan bisa menjadi percontohan dan memotivasi warga untuk bisa dibuat di setiap rumah dengan menggunakan bahan sederhana yang mudah didapatkan.

\section{UCAPAN TERIMA KASIH}

Penulis menyampaikan ucapan terima kasih yang sebesar-besarnya kepada semua Pihak yang banyak membantu dalam proses pelaksanaan KKN-PPM ini, yatu: Direktorat Jendral Riset dan Pengabdian Masyarakat Kemenristekdikti, Lembaga Layanan Dikti Wilayah IX Sulawesi (LLDIKTI), Ketua STIKES Bhakti Pertiwi Luwu Raya Palopo, Kepala Puskesmas Bantilang, Kepala Desa Loeha dan segenap tokoh masyarakat. 


\section{REFERENSI}

Awaluddin, R. 2009. Analisis pengaruh bimbingan teknis terhadap peningkatan keterampilan pegawai pada badan pengawasan daerah kabupaten Bogor, Jawa Barat. Skripsi. Bogor: Institut Pertanian Bogor.

Ayuningrum, F.V., Salamah, M. 2015. Analisis Faktor Sanitasi dan Sumber Air Minum yang Mempengaruhi Insiden Diare pada Balita di Jawa Timur dengan Regresi Logistik Biner. Jurnal Sains dan Seni ITS. 4(2):223-228. http:/ /dx.doi.org/10.12962/j23373520.v4i2.10 799

Darmanto, R.F. 2018. Pengaruh Budaya Kerja, Disiplin Kerja Dan Koordinasi Terhadap Kinerja Karyawan PT Kereta Api Indonesia (Persero) Daop 1 Jakarta. Jurnal Pengembangan Wiraswasta. 20(2):79-94. http://dx.doi.org/10.33370/jpw.v20i2.216

Erica, D. 2016. Hubungan Dan Pengaruh Bimbingan Belajar Terhadap Prestasi Belajar Siswa Pada Sma Kafah Unggul Tangerang. Cakrawala: Jurnal Humaniora Bina Sarana Informatika. 16(1):1-13.

https://doi.org/10.31294/jc.v16i1.1278

Food and Nutrition Research Institute. 2002. Recommended Energy and Nutrient Intakes Philippines, 2002 Edition. Manila: Food and Nutrition Research Institute Department of Science and Technology.

Gusdi, R. Wita, H., Septiana, U. 2017. Pembuatan Alat Penyaringan Air Sederhana Dengan Metode Fisika. Jurnal Nasional Ecopedon: JNEP. 4(1):1921.

Moll, D.M., McElroy, R.H., Sabogal, R., Corales, L.F., Gelting, R.J. 2007. Health impact of water and sanitation infrastructure reconstruction programmes in eight Central American communities affected by Hurricane Mitch. Journal of Water and Health. https:/ /doi.org/10.2166/wh.2006.047

Musawir, M.A., Arsin, A.A. 2014. Kontaminasi Bakteri Escherichia coli Pada Botol Susu Dengan Kejadian Diare Pada Bayi. Media Kesehatan Masyarakat Indonesia. 10(3):146-153. http://dx.doi.org/10.30597/mkmi.v10i3.487
Napitupulu, D.O., Damanik, I.R.T., Sitorus, E., Marta, E.D. 2017. Prevalensi Diare Pada Balita Di Puskesmas Sibiru-Biru Kecamatan Sibiru-Biru Deli Serdang Tahun 2015-2016. Jurnal Kedokteran Methodist. 9(9):728-733.

Nazarudin. 2016. Pengaruh Koordinasi Dan Pengawasan Terhadap Efektivitas Organisasi Di Lingkungan Pemerintahan Kabupaten Cianjur (Studi pada Sekretariat-sekretariat, Lembaga Teknis Daerah dan Dinas-dinas di lingkungan Pemerintahan Kabupaen Cianjur). Disertasi. Bandung: Universitas Pasundan.

Nurfita, D. 2017. Faktor-Faktor yang Berhubungan dengan Kejadian Diare pada Balita di Puskesmas Bulu Lor Kota Semarang. Kes Mas: Jurnal Fakultas Kesehatan Masyarakat. 11(2):149154.

http:/ /dx.doi.org/10.12928/kesmas.v11i2.71 39

Pemerintah Republik Indonesia. 2017. Instruksi Presiden Republik Indonesia Nomor 1 Tahun 2017 tentang Gerakan Masyarakat Hidup Sehat.

Raflis. 2015. Pengaruh Komunikasi Dan Tim Kerja Terhadap Keberhasilan Kolaborasi Desain Pada Konsultan Enjinering Di Yogyakarta, Solo, Dan Semarang. Tesis. Surabaya: Institut Teknologi Sepuluh November.

Raharjo, K., Mulyoto, M., Suryani, N. 2016. Pengaruh Penyuluhan Kesehatan terhadap Perilaku Hidup Bersih dan Sehat (PHBS) ditinjau dari Status Sosial Ekonomi (Studi Eksperimen Pada Mahasiswa Prodi DIII Keperawatan Poltekkes Bhakti Mulia Sukoharjo). Indonesian Journal on Medical Science (IJMS). 3(2):86-93.

Robertson, W., Stanfield, G., Howard, G., Bartram, J. 2007. Monitoring the Quality of Drinking Water During Storage and Distribution. In Dufour, A., Snozzi, M. Koster, W., Bartram, J., Ronchi, E., Fewtrell, L. (Eds.) Assessing Microbial Safety of Drinking Water: Improving Approaches and Methods. Paris: Organisation for Economic Cooperation and Development-World Health Organization.

Sukardi, D.K. 2000. Pengantar Pelaksanaan Program Bimbingan dan Konseling di Sekolah. Jakarta: Rineka Cipta. 
Sutomo, S. 1987. Water Supply and Diarrheal Disease in Rural Areas of Indonesia. Buletin Penelitian Kesehatan. 15(2):9-14.

Utami, S., Handayani, S.K. 2017. Ketersediaan Air Bersih Untuk Kesehatan: Kasus Dalam Pencegahan Diare Pada Anak. In Pangaribuan, N., Winarni, I., Toha, M., Utami, S. (Eds). Optimalisasi Peran Sains \& Teknologi untuk Mewujudkan Smart City. Jakarta: Universitas Terbuka. 